\title{
The Qur'an and Human Embryology: A Further Study
}

\author{
Dildar Ahmed, PhD \\ Preston University \\ Islamabad, Pakistan
}

DOI: http://dx.doi.org/10.5915/38-3-5985

\begin{abstract}
:
This is a study of the verses referring to human embryologic development in the Glorious Qur'an. While these verses can be included as part of the "scientific miracle" of the Qur'an, the author emphasizes that the actual intent is to draw attention to the creative power of God and His blessings on humans so they may become thankful.
\end{abstract}

Key words: Glorious Qur'an, Hadith, embryology, nutfa, 'alaqa, mudgha, Islamic Perspective

$T^{n}$ the last few decades, the embryological references in the Glorious Qur'an have attracted the attention of authors and scholars, including Maurice Bucaille ${ }^{1}$ and Keith L. Moore ${ }^{2}$, who have attempted to interpret the related verses according to modern embryologic findings. This paper is a continuation of such studies and attempts to highlight and explain the verses having an allusion to human embryologic development. An emphasis also has been given to the actual intent of the Qur'an behind such references, that is, to draw the readers' attention to the creative power of God alle and His blessings on them so that they may become thankful.

\section{The Signs of God}

The prenatal development of humans is a fascinating and awesome event. It begins with a single fertilized egg and culminates some 38 weeks later with a complex organization composed of billions of cells. ${ }^{3}$

According to the Glorious Qur'an, there are signs, messages or manifestations (āyāt) of God $\overline{a l}$ i the Creator, not only in the physical universe (the macrocosm) but also in the human beings (the microcosm):

Reprint requests should be directed to

Dildar Ahmed, PhD

Department of Chemistry

Hazara University

Mansehra, Pakistan

email:dildarahmed@gmail.com

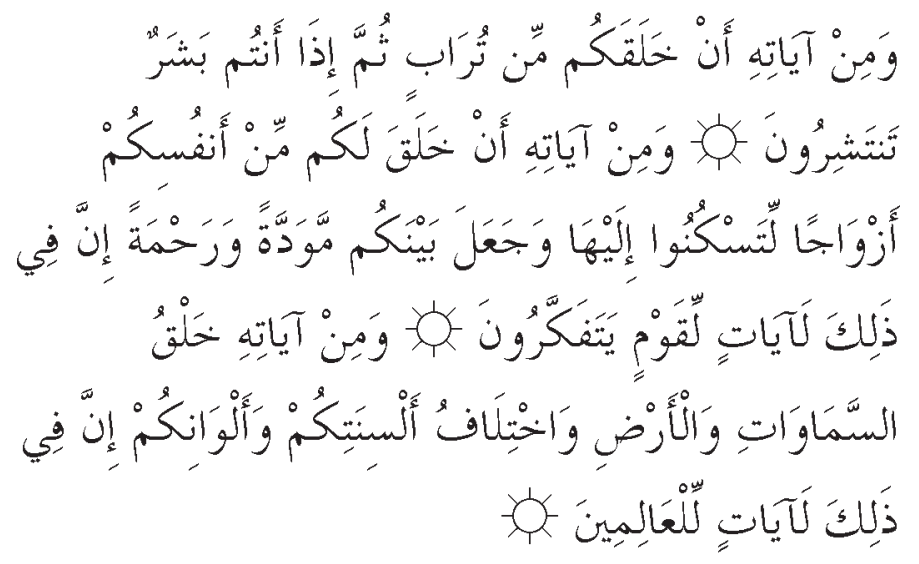

Among His Signs is this, that He created you from dust; and then, - behold, ye are men scattered (far and wide)! And among His Signs is this, that He created for you mates from among yourselves, that ye may dwell in tranquillity with them, and He has put love and mercy between your (hearts): verily in that are Signs for those who reflect. And among His Signs is the creation of the heavens and the earth, and the variations in your languages and your colors: verily in that are Signs for those who know. ${ }^{4}$

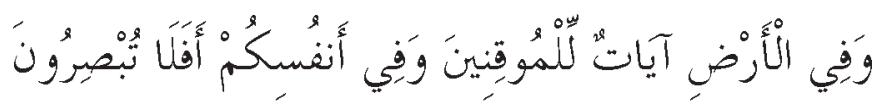

And on the earth there are signs (of God, visible) to all who are endowed with inner certainty, and also within your own selves: can you not, then, see? 5 
In the Glorious Qur'an there are many verses (āya $t$ ) scattered throughout the book that regard the phenomena of the universe, the macrocosm as well as the microcosm, as the signs of the AllPowerful and the Most Gracious Creator actual intent of the Qur'an being the Divine Book of guidance is for humans to acquire a cognition of God $\overrightarrow{a l i}$, as well as realize His blessings and bounties on them, and, therefore, be thankful to Him, thus fulfilling the purpose of their creation. The Qur'an says:

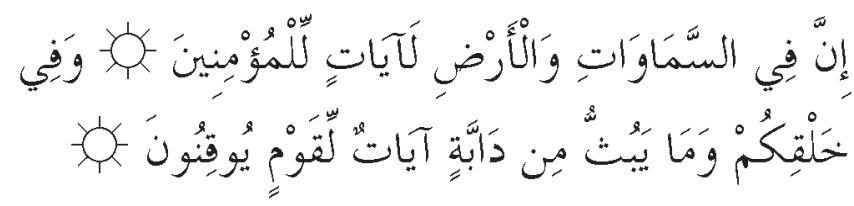

Behold, in the heavens as well as on the earth there are indeed signs for all who (are willing to) believe. And in your own creation, and in (that of) all the animals which He scatters there are signs for people who are endowed with inner certainty. ${ }^{6}$

Thus, in humans' own creation there are signs of God's creative power جلإل as well as His blessings on them.

Again and again the Qur'an draws the attention of its readers towards their coming into existence as human species, as well as their evolution as individuals in their mothers' wombs. Thus it says:

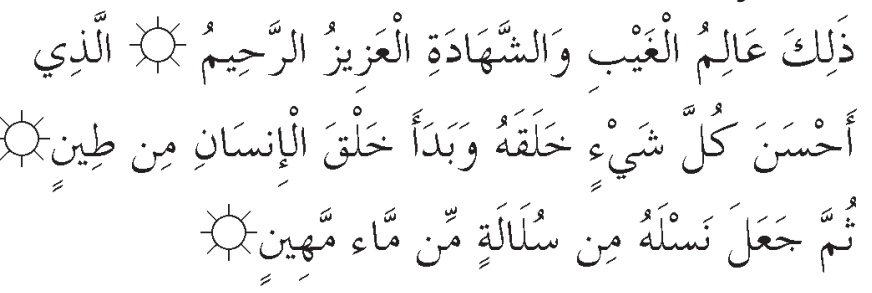

Such is He, the Knower of all things, hidden and open, the Exalted (in power), the Merciful. He who has made most excellent everything that $\mathrm{He}$ has created. Thus, He began the creation of man out of clay. And then He made his progeny out of a quintessence of a humble fluid. ${ }^{7}$

The meaning and the significance of the "quintessence of a humble fluid" will be explained.

At another place the Glorious Qur'an says:

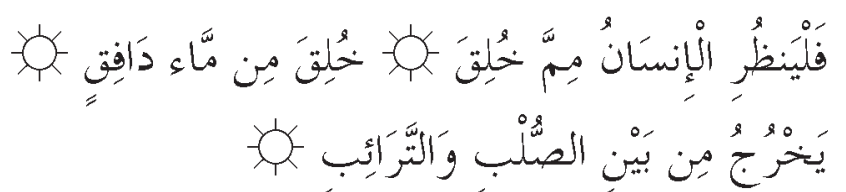

Let man, then, observe out of what he has been created. He has been created out of a seminal fluid issuing from between the loins (of man) and the pelvic arch (of woman). 8

The message is that human beings ought to realize their humble origin and, thus, know the Power (Qudra) of their Creator all who, starting from such a humble state, fashioned them into so highly excellent forms and shapes. Moreover, humans should be grateful to Him for His blessings on them.

The words șulb (loins) and țarā'ib (pelvic arch) used here in verse 86:7 have been interpreted in a number of ways. Maurice Bucaille offers the most satisfactory interpretation, that being "the sexual area of the man" and "the sexual area of the woman", respectively. ${ }^{1}$ According to Tāj al-'Arūs, most of the authorities who have specialized in the etymology of rare Qur'anic expressions believe that the tarâ'ib relates specifically to female anatomy. ${ }^{9-10}$

\section{Out of a Humble Fluid}

In connection with the creation of man, the Glorious Qur'an has used a term generally translated as "a humble fluid." Allah tis says:

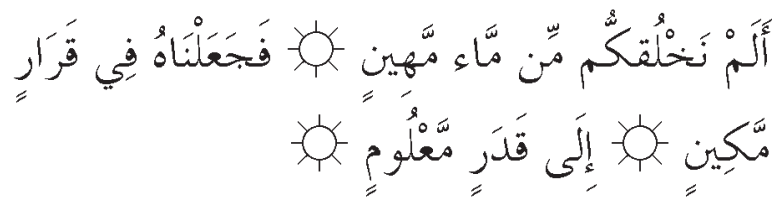

Did We not create you out of a humble fluid, which We then let remain in (the womb's) firm keeping for a term pre-ordained? ${ }^{11}$

The "humble fluid" denotes the germinal fluid, particularly that of the male, because that is known to even a layman and can be easily observed and reflected on to understand and realize the human's humble origin. The adjective mahin, translated here as "humble", can also be rendered as "despised". The latter

Editor's note: Tara'ib has also been interpreted as ribs and sulb as the spine. Between the sulb and tarä'ib is where both ovaries and testes are first developed before their downward migration. 
translation applies not so much on account of the nature of the liquid itself, but more due to the fact that it is emitted through the outlet of the urinary tract, using the channels that are employed for passing urine. ${ }^{1}$ It is God's creative power at that brings humans into being starting from an extremely humble and lowly state. At another place the Qur'an says:

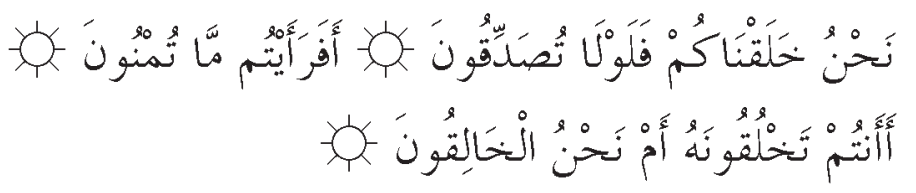

It is We who have created you: why, then, do you not accept the truth? Have you ever considered that (seed) which you emit? Is it you who creates it - or are We the source of its creation? ${ }^{12}$

Here "that (seed) which you emit" refers to both the male semen and the female ovum, and thus, by implication to the awe-inspiring, complex phenomenon of procreation as such. ${ }^{1}$

\section{Out of a Nutfa (drop)}

While drawing the human's attention towards their gradual development and evolution in the mother's womb, the Qur'an commonly uses a word nutfa. This has a number of meanings. Linguistically, according to the experts, it is used to describe "that small quantity" of a liquid that remains behind at the bottom of a bucket that has been emptied out.1,13,14 It therefore indicates a very small quantity of a liquid. (The word nutfa actually comes from a verb signifying "to dribble", "to trickle"). Keeping this in view, it can be loosely translated as "a drop" or "a small quantity of a liquid" ( $m \bar{a}$ ' qalìl). Evidently it is a comprehensive term and includes male and female gametes and part of their natural environments of fluid. It also includes the zygote, the morula and the blastocyst until implantation in the uterus. ${ }^{14}$ In a statement attrib-

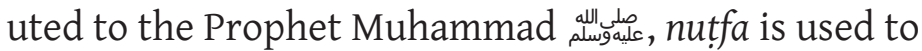
describe both male and female gametes. According to

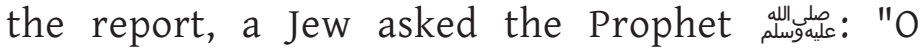
Mohammad! From what is man created? The Prophet replied: 'He is created from both the man's nutfa as well as the woman's nutfa."15

In the Qur'an nutfa has been used 12 times, and each time its connotation can be determined from the context:

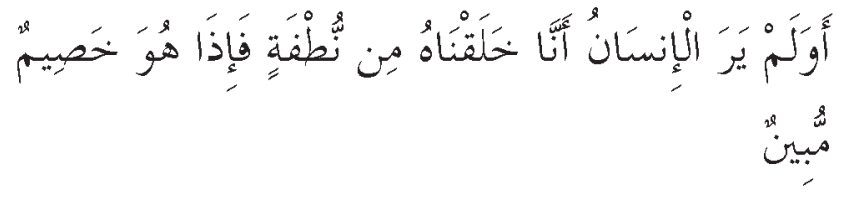

Is man, then, not aware that it is We who created him out of a (mere) drop - whereupon, lo! he shows himself endowed with the power to think and to argue? ${ }^{16}$

Here, nutfa signifies man's sperm, or the zygote that is formed by the combination or fusion of man's sperm with woman's ovum. The emphasis is on the fact that out of such a small thing, God alle creates a human able to think, argue, and innovate. At another place it reads:

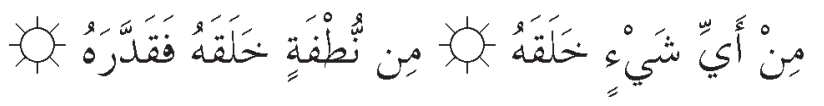

Does man ever consider out of what substance (God) creates him? Out of a drop He creates him, and thereupon determines his nature. ${ }^{17}$

In the following verses the word nutfa seems to be used in the meaning of a drop of man's sperm:

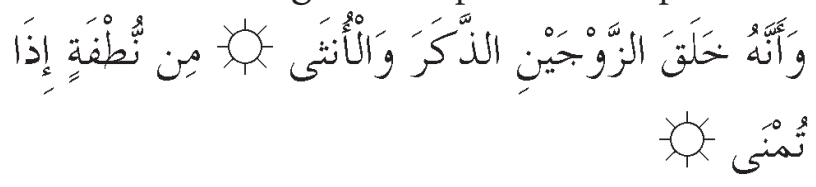

And that it is He who creates the two kinds - the male and the female - out of a (mere) drop (of sperm) as it is poured forth. ${ }^{18}$

Today, it is known that it is the sperm that determines the sex of the child. If the sperm having Y chromosome fertilizes the woman's ovum, the child will be a male, and if it is the sperm with $\mathrm{X}$ chromosome that fuses with the ovum, the child will be a female. Thus, it is a scientific miracle of the Qur'an to reveal such a reality long before the modern molecular biological and genetic discoveries.

And yet in a different context, the word amshāj qualifies the nutfa:

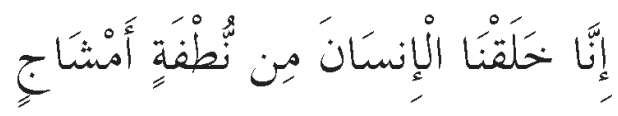

Verily, it is We who have created man out of an intermingled drop... ${ }^{19}$ 
Nutfa amshāj can be loosely translated as a "mixed drop" or "combined drop", "intermingled drop" or simply "mingled drop". Most authorities believe it means the thing formed from the combination of male and female genital fluids and thus it denotes the zygote, the fertilized ovum.

\section{The Quintessence of the Humble Fluid}

In this regard, another point that must receive our due attention is the previously cited Qur'anic description of the creation of human beings out of a quintessence of the seminal fluid:

... and then He made his progeny out of a quintessence of a humble fluid. ${ }^{7}$

The Arabic word translated here as "quintessence" is sulāla. If on the basis of some criterion we select a part out of a whole, that selected part will be the suläla of that whole. It can also be rendered as "extract" or "essence".

Today, we know that the male's seminal fluid contains millions of sperms, and it is only one sperm that fuses with the woman's ovum. Out of the estimated 200-600 million sperms present in an ejaculated seminal fluid and deposited in the vagina during sexual intercourse, only about 200 sperms reach the fertilization site. Most of them degenerate and are absorbed by the female genital tract and only one sperm, in normal conditions, fertilizes the ovum. ${ }^{20}$ Further, all the sperms are not identical. Half of the total sperms have X chromosomes and the other half have $Y$ chromosomes. That one single sperm - out of this abundance and variety - which fertilizes the ovum is really a sulāla, quintessence, of the male's seminal fluid. It is indeed God's willed laws that decide and choose a single particular sperm to fashion a human being.

\section{The Firmly Established Lodging}

A fertilized ovum is called a zygote, the Qur'anic nutfa amshāj. The zygote undergoes implantation in the womb (uterus), which possesses every thing that a tiny developing human needs: protection, food according to his/her requirements, and an environment where it can develop and grow according to his/her potential. The Qur'an says in another verse:

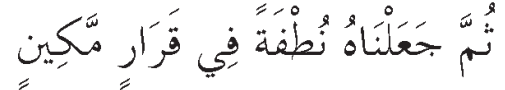

...And then We placed him as a small quantity (nutfa) in a safe lodging firmly fixed. ${ }^{21}$

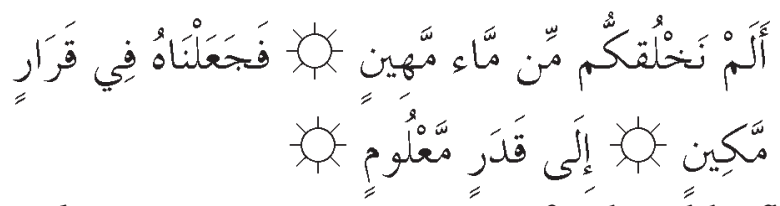

Did We not create you out of a humble fluid, which We then let remain in (the womb's) firm keeping for a term pre-ordained?11

The implantation of the zygote in the uterus is the result of the development of villi, veritable elongations of the zygote, which draw nourishment from the uterine wall. The vertebral column (backbone), pelvic bones and abdominal muscles of the mother's body make the womb a safe and protected place for the embryo. Inside the uterus, the embryo/fetus develops within the chorioamnion surrounded by the amniotic fluid. As a buoyant medium, the amniotic fluid performs four functions for the embryo and subsequent fetus: (1) it permits symmetrical structural development and growth, (2) it cushions and protects the embryo/fetus by absorbing jolts that the mother may receive, (3) it helps maintain consistent pressure and temperature, and (4) it allows the fetus to move freely, which is important for musculoskeletal development and blood flow. ${ }^{3}$ In such an environment the embryo undergoes development and growth, and gradually becomes a young human baby in a certain period of time.

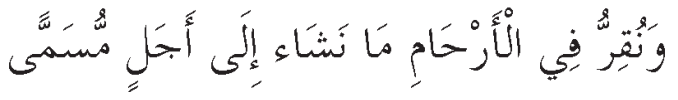

We cause whom We will to rest in the womb for an appointed term. ${ }^{22}$

\section{The Successive Stages}

In the mother's womb, the embryo undergoes gradual development passing through various successive stages:

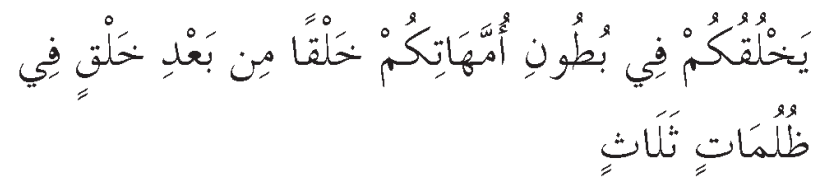

... He creates you in your mothers' wombs, one act of creation after another, in three darknesses. ${ }^{23}$ 
The "one act of creation after another" alludes to the successive stages of the embryonic development. The "three darknesses" or, as usually translated, "three veils of darkness" have been explained by the experts of embryology ${ }^{2}$ as follows:

1. The anterior abdominal wall,

2. The uterine wall, and

3. The amniochorionic membrane that surrounds the embryo. (See editor's note below.)

God $\mathrm{du}$ is the all-Seeing Creator who needs no light for making, shaping, developing, fashioning, and forming anything. His creative will operates equally both in the light and darkness.

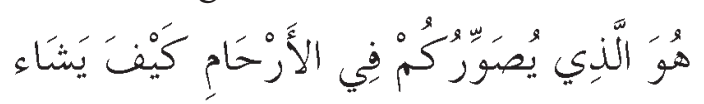

$\mathrm{He}$ it is who shapes you in the wombs as $\mathrm{He}$ wills ...24

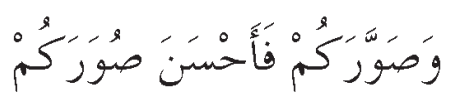

... He has formed you - and formed you so well ...25

The term "He has formed you" means He has given you your shapes as human beings.

\section{Details of the Stages}

The creative will of God alle causes the embryo to pass through various stages, each revealing a new facet of His creative power and design. The Glorious Qur'an says:
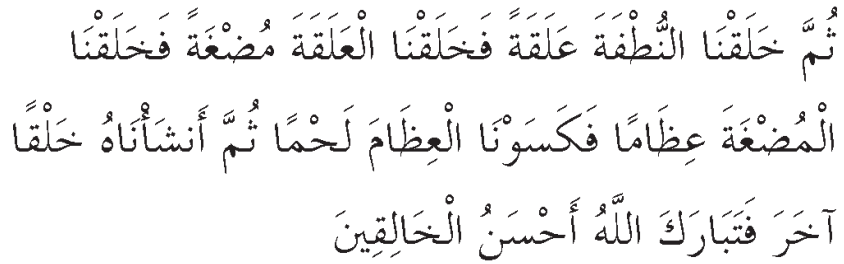

And then We fashioned out of the nutfa an 'alaqa, and We fashioned the 'alaqa into a mudgha and We fashioned the mudgha into bones and We clothed the bones with intact flesh - and then We bring (all) this into being as a new creation: hallowed, therefore, is God,

Editor's note: An alternate interpretation is that the three veils could be referring to the 1) decidua, the inner lining of the uterus, 2) chorion and 3) amnion, two extraembyonic fetal membranes the best of artisans. ${ }^{26}$

The nutfa (a small quantity, a drop) here seems to denote the zygote (fertilized ovum), that passes through various stages. The zygote changes to the 'alaqa (something that clings, implanted), which in turn develops into the mudgha (chew-like lump, the embryonic lump). The mudgha passes through further evolutionary process, as a result of which bones develop and the developing bones are clothed with intact flesh or muscles. As a result of these changes, the embryo acquires the form that gives it the characteristic human appearance, and it can be recognized as a human fetus (khalq äkhar). All this has been ordained by God and has been happening again and again ever since God brought humans into being. This description also emphasizes the debt of gratitude that humans owe to God for having endowed them with such an excellent form as well as with a spirit from His own.

For a better comprehension of the topic it would be appropriate to explain a little more the key terms used in the above verses. These terms are:

1. 'Alaqa (something that clings)

2. Mudgha (chewed-like lump)

3. 'Izām and lahm (formation of bones and flesh)

4. Khalq ākhar (a new creation)

\section{‘Alaqa}

The Arabic word 'alaqa has a number of meanings. In the present context, according to the experts of embryology, it is best rendered as "something that clings." 1 Other translations that can also be applied are "a leech-like structure"2, "suspended entity" etc.

Any Arabic dictionary or lexicon will show that the original meaning of 'alaqa is "anything that sticks to or hangs with something else". Familiar words such as ta'alluq, 'ilāqa, and mu'allaq are from the same root. It has many connotations. It was used for blood or congealed blood because of the easily observable property of blood being sticky as soon it starts to dry out. It was used for mud, because of its obvious property of sticking to the hands. It was used for leech because it sticks to its prey. If some previous scholars interpreted its Qur'anic usage to imply "a clot of blood", this was not because the word has only that meaning. Thus, translating 'alaqa as "a clot of blood" is not correct. Because the Glorious Qur'an exists in its original language, any misconception of its translation 
at any time will not affect the real meaning of its words.

After fertilization, the zygote, while passing through various changes, attaches itself (that is, implants) to the endometrium. The implantation of the zygote (now, blastocyst) commences at the end of the first week after fertilization and is completed by the end of the second week. The implantation of the embryo makes it literally cling to the uterus. As it clings to the uterine wall, it becomes suspended in the chorionic cavity by means of the connecting stalk and is surrounded by the amniotic sac. Therefore, 'alaqa represents the suspended embryo after it has been implanted. The clinging is most evident between day 7 to about day 24. On this basis, therefore, 'alaqa can very appropriately be rendered as "something that clings".

At this stage the embryo resembles a leech in its appearance as well as in its way of obtaining nourishment. If an embryo at 24 days is seen from the side, it resembles a leech. Moreover, the embryo is now dependent on the maternal blood for its nutrition and in this way it behaves very much like a leech.

\section{Mudhgha}

The 'alaqa transforms into another stage described as mudgha. Literally, mudgha means a chewed substance, chewed lump, something which has been chewed, specifically a piece of meat, or something that has the appearance of having been chewed. ${ }^{26-7}$ The experts of embryology have confirmed that "toward the end of the fourth week, the human embryo looks somewhat like a chewed lump of flesh." 2 The chewed appearance results from the somites, which give the appearance of teeth marks. The somites represent the beginnings or primordia of the vertebrae.

The mudgha represents the stage of embryo's development in which the bones have not yet formed, as the Qur'an says that God alis fashions bones out of mudgha. ${ }^{26}$ Up to the mudgha stage a lot of changes have taken place, and it has both differentiated and undifferentiated tissues. The Qur'an says:

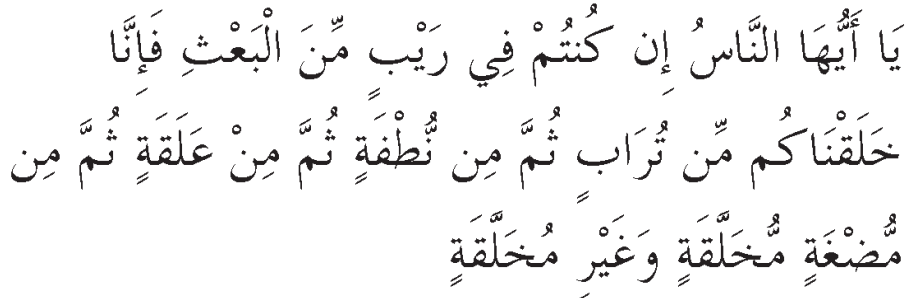

O Mankind, if you have a doubt about the resurrection, (consider) that We have created you out of dust, then out of a drop (nutfa), then out of something that clings (alaqa), then out of a chewed like lump of flesh (mudgha) partly formed and partly unformed ...22

The "chewed like lump of flesh partly formed and partly unformed" can be understood to describe the internal structure of the embryo. In the embryo of mudgha stage, some tissues are in a differentiated form and some are in an undifferentiated form. "For example, when the cartilage bones are differentiated, embryonic connective tissue or mesenchyme around them is undifferentiated. It later differentiates into the muscles and ligaments attached to the bones." 1 It is also known that although the anlage of all organ systems have formed by about 4-6 weeks embryonic age, their function has yet to appear. As they become more differentiated, their function appears accordingly. (See editor's note below.)

\section{Formation of Bones and Flesh}

As an embryo further evolves from the mudgha stage, the skeletal system (bones) develops. The bony structures develop inside the mudgha in what is called the mesenehyme. ${ }^{1}$ Although bone formation, or ossification, begins about the fourth week of embryonic development, ossification centers cannot be readily observed until about the tenth week. ${ }^{3}$ By the beginning of the seventh week, the embryo has acquired a skeleton, mostly cartilaginous, which gives form to the body of the embryo and recognizable human characteristics. ${ }^{14}$ The bones are not formed in such a way that they are naked or uncovered, but the creative wisdom of the Almighty Creator develops them in such a way that they are "clothed" with flesh (muscles):

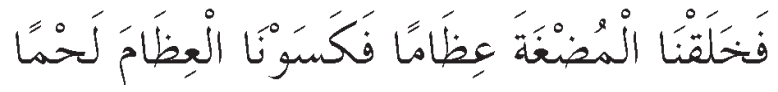

We fashioned the chewed like lump into bones and We clothed the bones with intact flesh. ${ }^{2}$

The primordia of both the bones and muscles are formed during the first 40 days in the form of

Editor's note: Another interpretation is that "formed" refers to the embryo and "unformed" refers to the placenta. See M. Shoukfeh, MD, J Islam Med Assn 2006;28:50-6. 
myotomes and sclerotomes. During the seventh week the skeleton begins to spread throughout the body, and at the end of the seventh week and during the eighth week the muscles take their position around the bones. ${ }^{14}$

Thus, the formation of bones and muscles in the fetus not only shows the creative wisdom and power of Almighty God ali but also His great blessing on us. This provides us with an opportunity to acquire God's cognition as well as the opportunity to be grateful to Him. This is what the central aim of the Glorious Qur'an is. It is, in fact, the bones and the muscles, the formation and development of which transforms a mere lump into a human fetus with characteristic human form and shape.

\section{A New Creation}

During the embryonic period all organ systems are formed. As a result, the embryo acquires the characteristic human form and features by the end of the eighth week. Now, the embryo is called a fetus. This fetus is recognizable as a human being at the ninth week. ${ }^{3} \mathrm{~A}$ small amount of tissue differentiation and organ development still occurs during the fetal period but for the most part, the fetal development is primarily limited to the body growth. ${ }^{2}$ The Glorious Qur'an describes this transformation as khalq äkhar, a new, or another, creation. This again calls a human being to acknowledge the creative power as well as the blessing of God.

\section{The Signs of God's Power and Blessings}

It is God's will that brings into existence a human being with such a remarkable body and mind. The food we eat is synthesized in plants out of nonliving inorganic material through a process called photosynthesis. A plant absorbs water and minerals from soil with the help of its roots. It absorbs carbon dioxide from air, and then, using these ingredients in its green parts, it prepares food with the help of sunlight.

When we eat food, it is assimilated and becomes part of our body, including the reproductive organs that produce gametes. The male and female gametes - sperm and ovum - combine in the mother's womb to form a single cell called zygote.

During an ejaculation many hundred millions of sperms are emitted but only one fertilizes the ovum. Similarly, out of some 40,000 to 400,000 follicles in a woman's ovaries, only one forms an ovum that is to be fertilized and that will form the future person.

It is God-willed law that constantly operates and selects the particular sperm and particular ovum to create the future person, a male if the sperm containing the $\mathrm{Y}$ chromosone is selected or a female if the sperm containing the $\mathrm{X}$ chromosone is selected.

These divinely selected ovum and sperm combine (that is, undergo fertilization process) to form a zygote. A zygote is a small cell. It undergoes successive cell divisions and is then implanted in the mother's womb, which provides it both protection and sustenance. In the beginning, a human being is thus a single cell, and then it becomes an aggregate of a ball of a few cells. These similar cells, through successive cell divisions, form organs so different from one another and eventually a human being. It is this God-programmed system of evolution that gives rise to all this differentiation and organization. Every step of this evolutionary process reveals God's Wisdom, Almightiness, Omniscience, Majesty, Beneficence and Graciousness and it is a sure sign of His rubūbiyya لjuli.

Thus, man's own creation provides him with an opportunity to: (1) understand the Majesty and Power (Qudra) of God alis, and (2) realize His blessings on him.

\section{References}

1. Bucaille M. The Bible, the Qur'an and science. Translators. Pannell AD and the author. 1st ed. Indianapolis, IN: American Trust Publications; 1979.

2. Moore KL. A scientist's interpretation of references to embryology in the Qur'an. J IMA. 1986 Jan;18:15-7. http://dx.doi.org/10.5915/18-1-8693

3. De Graaff V, Fox S. Concepts of Human Anatomy and Physiology. 4th ed. Sydney: W.C. Brown, 1995.

4. Glorious Qur'an, 30:20-2.

5. Glorious Qur'an, 51:20-1.

6. Glorious Qur'an, 45:3-4.

7. Glorious Qur'an, 32:6-8.

8. Glorious Qur'an, 86:5-7.

9. Muhammad Murtaḍa al-Husayni al-Zabidi. Tāj al'Arūs. Kuwait City: Maṭba'a Ḥukūma al-Kuwait, 1966, Vol. 2.

10. Mohammad Asad. The message of the Qur'an. Gibraltar: Dar al-Andalus Limited, 1980.

11. Glorious Qur'an, 77:20-2.

12. Glorious Qur'an, 56:57-9.

13. Muhammad b. Mukarram b. 'Ali b. Ahmad b. Mandhūr (d. 711/1312). Lisān al-`Arab. Dar al-Jīl 
Beirut, 1988.

14. Moore KL, Azzindani AA. The developing human: clinically oriented embryology with Islamic additions. 3rd ed. Jeddah: Dar al-Qiblah, 1983.

15. Ahmad b. Hanbal. Al-Musnad. Vol. 1. Musnad 'Abdullah b. Mas'ūd. Available from http://www.muhaddith.org.

16. Glorious Qur'an, 36:77.

17. Glorious Qur'an, 80:18-9.

18. Glorious Qur'an, 53:45-6.

19. Glorious Qur'an, 76:2.
20. Moore KL, Persaud TVN. The developing human. Philadelphia: W.B. Saunders Company, 1998.

21. Glorious Qur'an, 23:13.

22. Glorious Qur'an, 22:5.

23. Glorious Qur'an, 39:6.

24. Glorious Qur'an, 3:6.

25. Glorious Qur'an, 64:3.

26. Abu al-Ḥusayn Aḥmad b. al-Fāris. Maqāyīs allugha. Beirut: Dar al-Kutub al'Ilmiyya, 1420/1999.

27. Ismā’ìl bin Hammād al-Jawhari (d. 1010). Tāj allugha wa siḥ̂ḥ al-`arabiyya. Cairo, 1972. 